\title{
Modelling molecular and inorganic data of Amanita ponderosa mushrooms using artificial neural networks
}

\author{
Cátia Salvador • M. Rosário Martins • \\ Henrique Vicente $\cdot$ José Neves · José M. Arteiro • \\ A. Teresa Caldeira
}

Received: 3 January 2012/Accepted: 9 July 2012 / Published online: 24 July 2012

(C) Springer Science+Business Media B.V. 2012

\begin{abstract}
Wild edible mushrooms Amanita ponderosa Malençon and Heim are very appreciated in gastronomy, with high export potential. This species grows in some microclimates, namely in the southwest of the Iberian Peninsula. The results obtained demonstrate that $A$. ponderosa mushrooms showed different inorganic composition according to their habitat and the molecular data, obtained by M13-PCR, allowed to distinguish the mushrooms at species level and to
\end{abstract}

C. Salvador $\cdot$ H. Vicente $\cdot$ J. M. Arteiro .

A. T. Caldeira $(\square)$

Department of Chemistry and Évora Chemistry Centre,

University of Évora, Rua Romão Ramalho n ${ }^{\circ} 59$,

7000-671 Évora, Portugal

e-mail: atc@uevora.pt

C. Salvador

e-mail: katia_salvador@hotmail.com

H. Vicente

e-mail: hvicente@uevora.pt

J. M. Arteiro

e-mail: jmsa@uevora.pt

M. R. Martins

Chemistry Department and Institute of Mediterranean

Agricultural and Environmental Sciences, University

of Évora, Rua Romão Ramalho n`59, 7000-671 Évora,

Portugal

e-mail: mrm@uevora.pt

J. Neves

Department of Informatics, University of Minho,

Braga, Portugal

e-mail: jneves@di.uminho.pt differentiate the A. ponderosa strains according to their location. Taking into account, on the one hand, that the characterisation of different strains is essential in further commercialisation and certification process and, on the other hand, the molecular studies are quite time consuming and an expensive process, the development of formal models to predict the molecular profile based on inorganic composition comes to be something essential. In the present work, Artificial Neural Networks (ANNs) were used to solve this problem. The ANN selected to predict molecular profile based on inorganic composition has a 6-7-14 topology. A good match between the observed and predicted values was observed. The present findings are wide potential application and both health and economical benefits arise from this study.

Keywords Ectomycorrhizal macrofungi - Wild edible mushrooms · M13-PCR · Inorganic composition $\cdot$ Artificial intelligence based tools 